\title{
Advanced Lung Non-Small Cell Squamous Carcinoma
}

National Cancer Institute

\section{Source}

National Cancer Institute. Advanced Lung Non-Small Cell Squamous Carcinoma. NCI

Thesaurus. Code C153201.

Non-small cell squamous lung carcinoma that has spread extensively to other anatomical sites or is no longer responding to treatment. 